\title{
SIMULATION OF BIOCLIMATIC SYSTEMS IN DETACHED HOUSES: REDUCED ENERGY DEMAND BY USING SPACE IN THE BASEMENT
}

\author{
FERNANDO ECHARRI IRIBARREN ${ }^{1}$, VÍCTOR ECHARRI IRIBARREN ${ }^{2}$ \\ \& ALMUDENA ESPINOSA FERNÁNDEZ ${ }^{3}$ \\ ${ }^{1}$ Department of Biology, University of Navarra, Spain \\ ${ }^{2}$ Department of Building Construction, University of Alicante, Spain \\ ${ }^{3}$ Department of Architecture, University of Zaragoza, Spain
}

\begin{abstract}
The climate conditions of the Mediterranean coast in Spain require a high energy demand in detached houses. Traditionally, vernacular architecture obtained an air interior temperature in summer of around $26^{\circ} \mathrm{C}$ - in principle quite comfortable because the superficial temperature of the walls was less than $23^{\circ} \mathrm{C}$ - by using masonry walls of around $50 \mathrm{~cm}$ in thickness. However, the high amount of air infiltrating through doors and windows, together with the difficulty of expelling the water vapour generated by people, meant that in practice the conditions of comfort were less satisfactory. Modern architecture changed these building patterns. Multi-layered walls are achieved with much less thickness, usually giving a $4 \mathrm{~cm}$ thick layer of insulation and an air chamber. With this, the thermal inertia is greatly reduced. But the most relevant factor of change is the increase in the glass area of these houses. Although double glazing substantially reduces the thermal transmittance value, the energy demand is considerably higher. However, structural techniques make it possible to introduce bioclimatic systems that can be put to advantage. This research looks into the benefits of having living space in the basement, as a method of passive temperature control in summer. We studied a detached house on the coast of Alicante, where the moderate temperature of the ground tempers the interior conditions of comfort using the flow of air from the basement towards the upper floors, significantly reducing the energy demand. This reduction was quantified through simulations with the tool Design Builder, in the scenarios of a traditional house, a house without basement and one with basement. Lastly, due to its importance, we quantified the role of air infiltration through the enclosure in that demand for energy. The results obtained are significant. In summer, it's possible to reduce in $3^{\circ} \mathrm{C}$ the indoor air temperature in the ground floor, obtaining an improvement in the user comfort sensation of $85 \%$. Annual energy demand is reduced by $18 \%$ compared to traditional buildings. The layout of the basement, as a passive system in the studied houses, reduces that energy demand by $20 \%$ more.
\end{abstract}

Keywords: passive systems, temperature control, energy demand, simulation, air infiltration.

\section{INTRODUCTION}

The standard of housing construction quality is lower in the Spanish Levante than in other regions in the north and interior of Spain. The regulations applied in the 1970s were very lax as regards parameters such as thermal transmittance, air permeability of windows and doors and the reduction of thermal bridges. In recent years, however, the Spanish Technical Building Code has established more demanding standards. The DB-HE technical document on energy efficiency [1] specifies the application of the Lider-Calener unified tool (Spanish acronym: HULC) [2] to single and multiple unit housing projects. This tool models the project and applies a built-in climate file that takes site location and altitude into account to generate a value for energy demand in winter and summer and an energy rating based on the heating, ventilation and air conditioning (HVAC) systems and energy sources employed in the building.

Although the HULC unquestionably represents a significant advance, it lacks the capacity to perform an accurate or calibrated simulation of the building's real performance when 
occupied. Furthermore, it does not offer the possibility of incorporating some of the bioclimatic techniques commonly employed in architecture [3]. These deficiencies represent a significant limitation that does not encourage application of the tool for housing projects. As a result of energy policies that are sometimes insufficiently founded, more value is placed on the use of particular energy sources than on the implementation of passive HVAC systems when calculating the energy rating of these buildings. A final limitation is that the HULC tool has very little capacity to model the building in use. For example, none of the following can be modelled: opening or closing windows at given times of the day, adjusting solar protection systems according to the need to collect or dissipate solar energy, use of the thermal inertia of the external walls to provide thermal comfort or use of phase change materials to reduce energy demand [4]. In contrast, other tools such as Design Builder do have the capacity to model these aspects in an occupation scenario and to incorporate bioclimatic techniques and passive HVAC systems.

\section{TRADITIONAL ARCHITECTURE IN ALICANTE}

Vernacular architecture in the province of Alicante took various forms based on the same construction system [5]. The structure consisted of load-bearing stone masonry walls between 40 and $50 \mathrm{~cm}$ thick, and pine joists or hollow brick vaulting supporting wooden floor slabs. The width between load-bearing walls ranged between 4 and $5 \mathrm{~m}$, generating prismatic volumes which might surround a courtyard or an area for livestock, or could simply form a solid block (Fig. 1). Irrespective of the different forms, interior comfort was achieved through the thermal inertia of the external masonry walls, into which only very small openings were made for interior lighting. Protection against solar radiation in summer was the decisive factor.

The inertia of the masonry walls provided insulation against heat from the sun and ensured satisfactory conservation of indoor heat generated by fireplaces or braziers in winter. Despite the high rate of air infiltration through the building envelope, the indoor air temperature in housing near the coast was approximately $17^{\circ} \mathrm{C}$ in winter and $26^{\circ} \mathrm{C}$ in summer. In addition to this technique for regulating the indoor temperature, houses sometimes had a south-facing

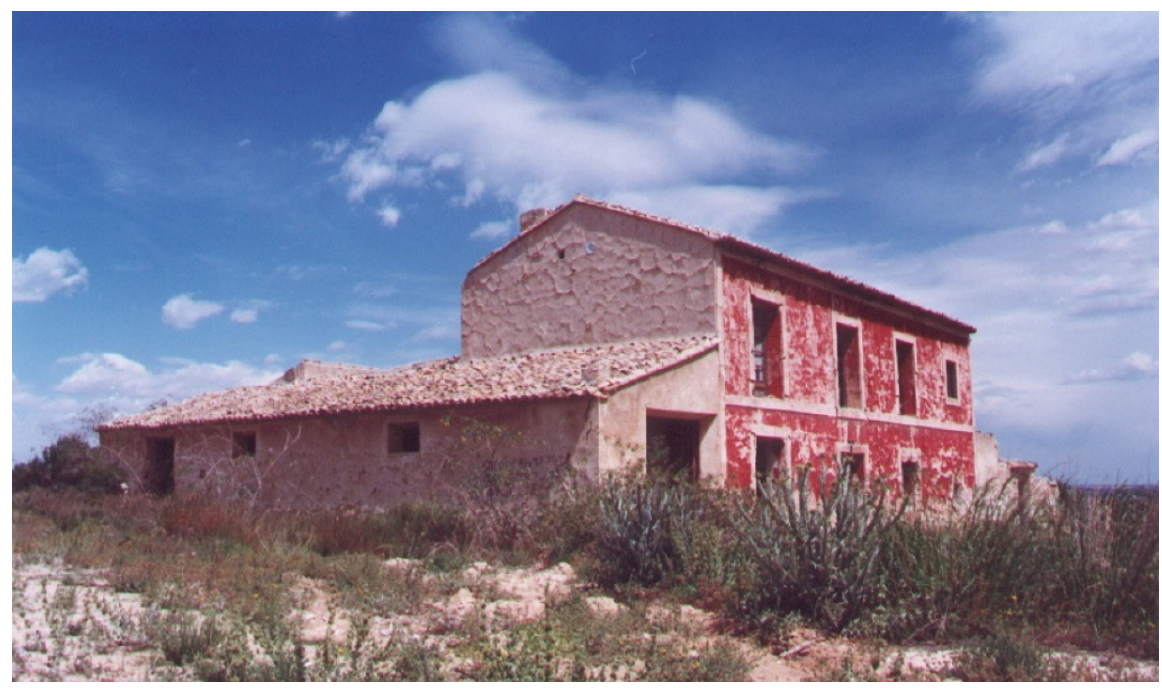

Figure 1: Example of traditional housing in the province of Alicante. 
porch that improved living conditions in the summer by providing shade and allowing natural air currents to moderate the high temperatures and relative humidity of outside air. Despite the good conditions for the summer, the performance of traditional houses in winter is very poor by current standards. To achieve operating temperatures within the limits required by the RITE (CTE), that is, from 20 to $23^{\circ} \mathrm{C}$, and comply with the annual energy demands (HULC), energy rehabilitation measures should be adopted, such as replacing carpenters and blinds Watertight to the infiltration of the air, insulation in façades and decks of at least $4 \mathrm{~cm}$ of thickness, and concrete bases with insulation incorporated in contact with the land.

\section{MODERN BUILDINGS AND PASSIVE SYSTEMS}

After the advent of modern architecture, traditional building styles underwent a radical transformation. In 1979, standard NBE-CT-79 [6] established the obligatory use of reinforced concrete structures and cavity walls filled with insulation, modifying patterns of performance in terms of interior comfort and energy demand. The use of large windows with no protection from the sun has worsened effective indoor temperatures, mainly in summer, an effect exacerbated by the high air permeability of building envelopes due to deficiencies in construction quality and the lax regulatory requirements of the NBE-CT-79 and the Spanish Technical Building Code. The proliferation of air conditioning systems in residential buildings, often installed years after their construction, indicates the failure of a building policy that has not taken the importance of comfort and energy efficiency into consideration. In contrast to standards such as the passivhaus of Central Europe, with energy demands below $15 \mathrm{kwh} / \mathrm{m}^{2} \mathrm{a}$ in winter, energy demands in the Spanish Levante usually range between 25 and $50 \mathrm{kwh} / \mathrm{m}^{2} \mathrm{a}$.

\section{CASE STUDY: SINGLE-UNIT DWELLING IN ALBUFERETA}

In line with these considerations, here we report a single unit dwelling located near Albufereta beach in Alicante. The house consists of a basement, a ground floor and a first floor, with a total surface area of $346 \mathrm{~m}^{2}$ (Figs 2-5). In an initial project, the house was designed without a basement, but due to poor soil resistance the cost of the foundations exceeded the construction budget. Consequently, a basement was placed under the entire surface area, so that the loads created by land excavation were compensated by those introduced by the new building.

This resulted in a radically different housing design from the original as regards both the distribution of spaces and uses and the environmental characteristics of the interior space. As the basement measured $142 \mathrm{~m}^{2}$, much more space than that required for a garage, storage and appliances, it was decided to incorporate a secondary living area and a guest bedroom with a full bathroom. In addition, it was decided to harness the constant ground temperature to ensure environmental comfort, i.e. to leverage the moderate temperatures of the reinforced concrete retaining walls to obtain a spacious, cool living area for use in the summer. A geotechnical study also revealed the presence of a water table 1.5 metres below surface level, because the plot was near the Albufereta beach. This circumstance, which required the use of waterproof concrete with a system of watertight structural joints, could be harnessed to provide greater stability of interior wall surface temperatures. This was measured by monitoring over the course of a full year. The mean surface temperature was $16.3^{\circ} \mathrm{C}$, with a maximum deviation of $2.9^{\circ} \mathrm{C}$. In the final design, the stairs leading from the basement to the ground floor were open-plan and located in a central position (Fig. 4), generating a passive HVAC system by means of indoor air convection currents, and thus reducing energy demands and increasing comfort. In summer, this system could be supplemented by opening the large 
glass doors in the ground floor living room, which gave onto the garden. As we describe in further detail below, this design eliminated the need to use an air conditioning system in summer. In winter, however, due to climatic conditions and the air permeability of doors and windows, a heating system was installed consisting of hot water radiators, sunk into the floor beside the large glass walls.

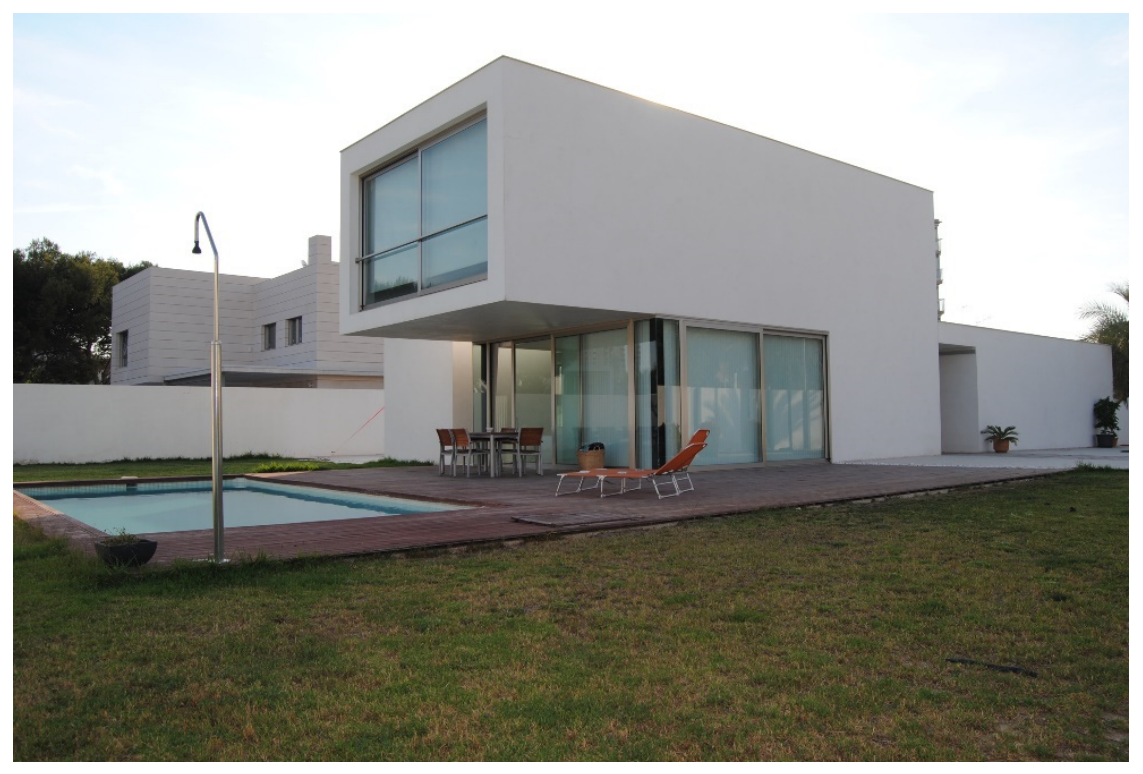

Figure 2: North-east view of the house Albufereta beach, Alicante.

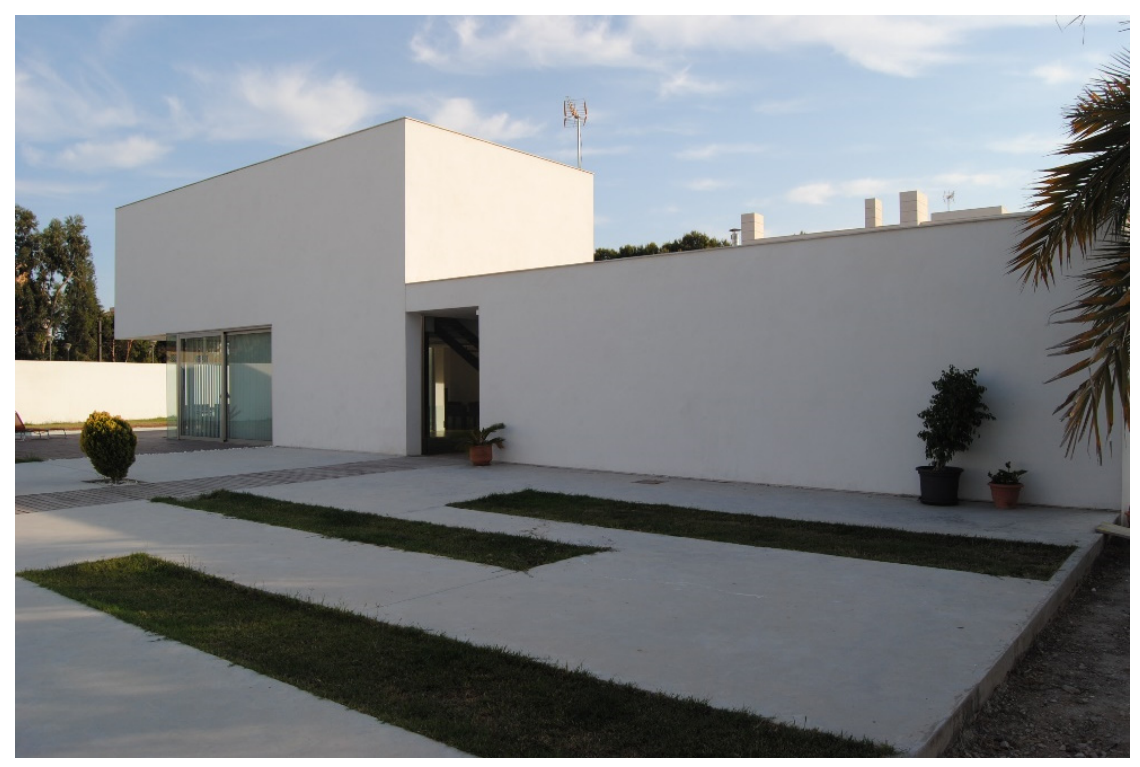

Figure 3: North view of the house Albufereta beach, Alicante. 

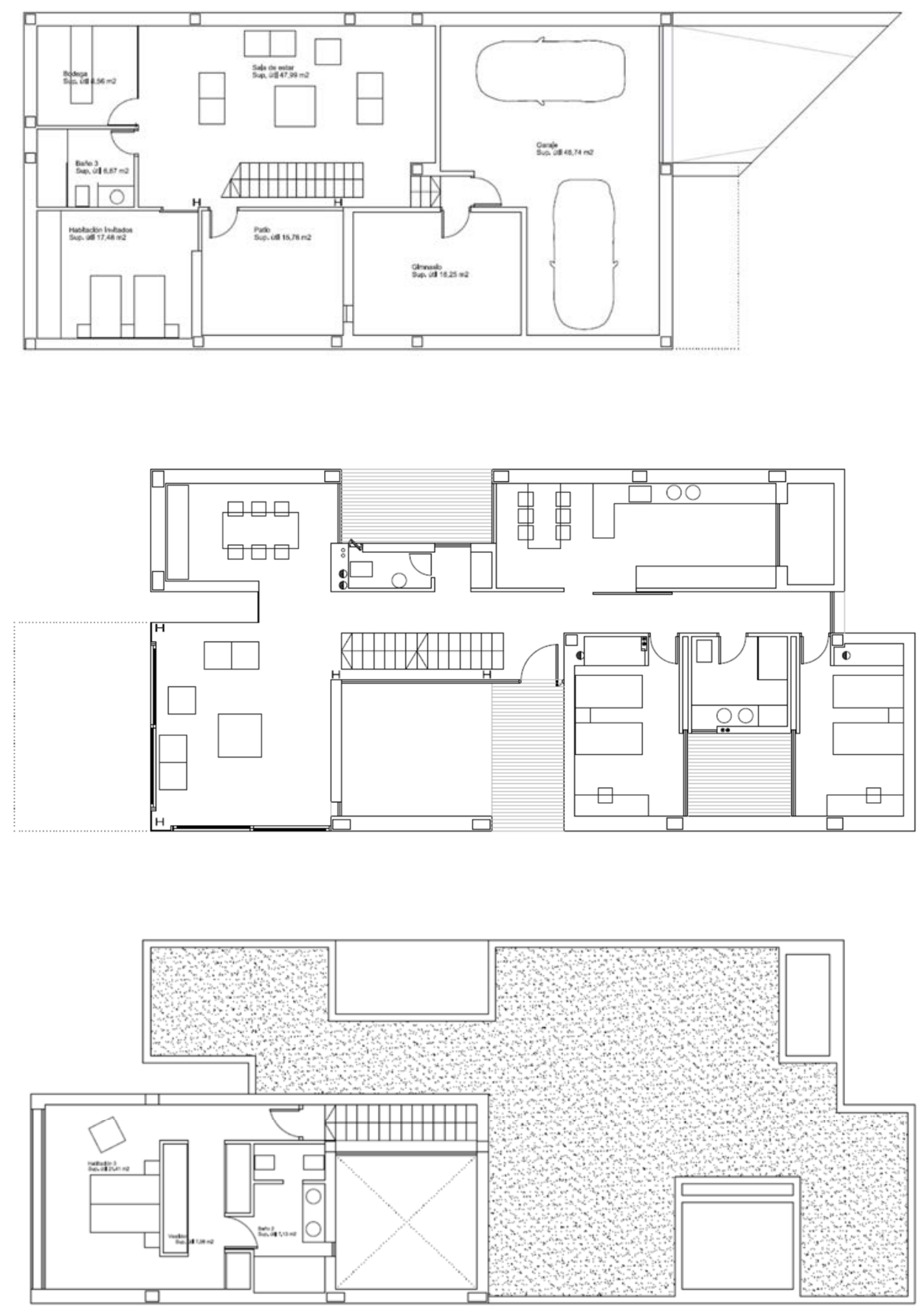

Figure 4: Basement, ground floor and first floor of the house. 


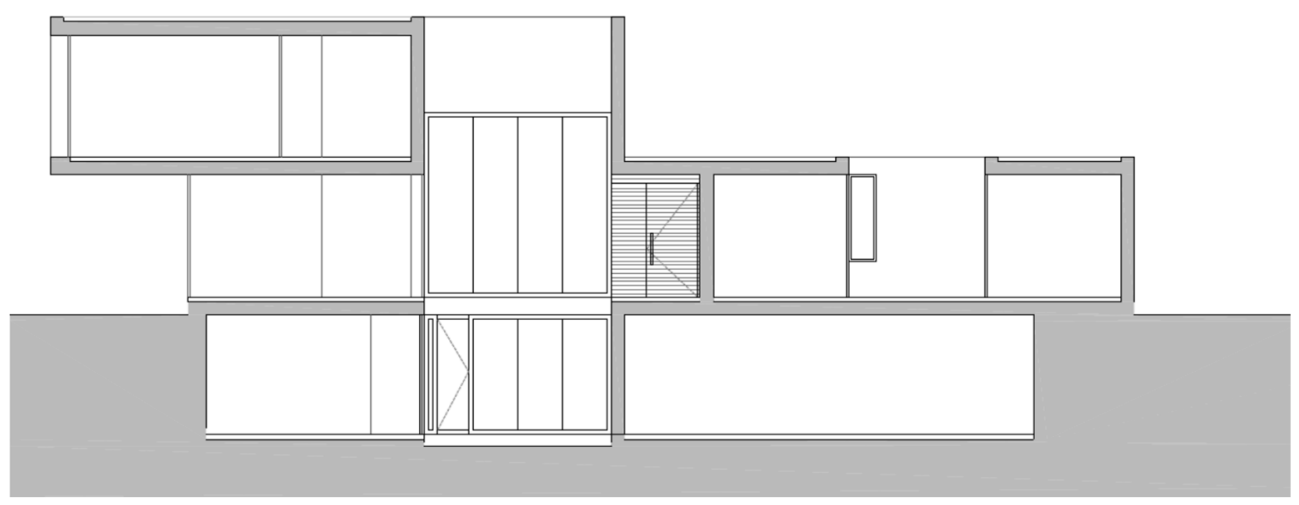

Figure 5: Longitudinal section through the courtyard.

\section{MAIN ENVIRONMENTAL COMFORT PARAMETERS}

To assess the apparent temperature, we employed a modified version of the protocol defined by Fanger [7], using new formulations adapted to specific architectural spaces [8]. Individuals need to maintain a fairly constant body temperature between 36.5 and $37^{\circ} \mathrm{C}$. The sensation of comfort requires maintenance of the energy balance according to the expression:

$$
\sum q=q_{m e t}-q_{e v} \pm q_{c i} \pm q_{c v i} \pm q_{r d i}=0 .
$$

Determining the ideal temperature and relative humidity to ensure normal indoor activities is a complex task that has prompted numerous studies [9], [10]. Heat loss by convection is obtained from the expression:

$$
q_{c v i}=h_{c}\left(T_{i}-T_{a}\right) \quad\left(\mathrm{W} / \mathrm{m}^{2}\right) .
$$

Convection factor $h_{c}$ is directly related to air velocity and the location of the individual. Generally, this factor has an average value of $3.5 \mathrm{~W} / \mathrm{m}^{2 \circ} \mathrm{C}$ with an air velocity of $0.1 \mathrm{~m} / \mathrm{s}$, and $4.5 \mathrm{~W} / \mathrm{m}^{2 \circ} \mathrm{C}$ with an air velocity of $0.2 \mathrm{~m} / \mathrm{s}$. The value can be obtained with the expression:

$$
h_{c}=8.3 v^{0.24} \quad\left(\mathrm{~W} / \mathrm{m}^{20} \mathrm{C}\right)
$$

Since the average value for the body surface is $1.7 \mathrm{~m}^{2}$ (24), expression (3) can be simplified to calculate total convection losses from the body:

$$
h_{c}=14.11 v^{0.24} \quad\left(\mathrm{~W} /{ }^{\circ} \mathrm{C}\right) .
$$

Obtaining the value of radiant heat loss, based on the Stefan-Boltzmann law, is more complex. Fanger quantified the form factors that affect determination of the true value of the mean radiant temperature of wall surfaces (20). The expression for the calculation of $T_{r m}$ can be simplified using the expression contained in his manual:

$$
T_{m r t}=T_{1} \cdot F_{P-1}+T_{2} \cdot F_{P-2}+\cdots+T_{N} \cdot F_{P-N} \cdot
$$


Using the mean radiant temperature thus obtained and the value of the temperature of an individual's skin and/or clothing, the value of radiant heat transfer can be obtained experimentally, assuming an approximate value for the coefficient of radiant heat loss $h_{r}$ of $4.7 \mathrm{~W} / \mathrm{m}^{2 \circ} \mathrm{C}$ with an estimable human body temperature $T_{i}$ of $30^{\circ} \mathrm{C}$.

$$
q_{r d i}=h_{r}\left(T_{i}-T_{r m}\right) \quad\left(\mathrm{W} / \mathrm{m}^{2}\right)
$$

Assuming a priori that relative humidity and air velocity values are maintained within the framework established by the Spanish regulation on heating installations in buildings (between 40 and $60 \%$ and 0.15 to $0.24 \mathrm{~m} / \mathrm{s}$, respectively, depending on whether it is winter or summer), an individual's sensation of comfort indoors depends on the surrounding air temperature $T_{a}$ and the surface temperature of all the walls that enclose the space $T_{r m}$.

However, little research has been conducted on the effect that the thermal inertia of a building's walls exerts on comfort and energy consumption [11]. Standard UNE EN ISO 13786 [12] describes how to assess the contribution of construction elements to a building's energy efficiency and consumption. The properties to consider include thermal admittance, which relates heat flow and temperature differences, and dynamic heat transfer properties, as a factor that moderates and delays temperature variations [11].

\section{PASSIVE COOLING SYSTEM USING THE BASEMENT}

Authors such as Bedoya and Neila have described the bioclimatic techniques most frequently employed in architecture depending on climate, such as the glasshouse effect, Trombe wall, stack effect, evaporative cooling and Canadian wells [3]. The present study focused on the capacity of the thermal inertia of the ground, harnessed via the retaining walls and floor slab in contact with the ground, to cool the indoor air in summer on the ground floor and in the basement, and to moderate low temperatures in winter. It was also necessary to design an efficient system of communication between the floors that would allow the air to circulate in summer and cool the rooms naturally. The placement of walls with a mean radiant temperature of $16.3^{\circ} \mathrm{C}$ in the basement and $19.5^{\circ} \mathrm{C}$ on the ground floor would provide a satisfactory level of body heat loss $q_{r d i}$. Furthermore, the convection currents generated would reduce indoor air temperatures on the ground floor by around $3.2^{\circ} \mathrm{C}$, with an air velocity of around $0.05 \mathrm{~m} / \mathrm{s}$. If a higher level of cooling were required in peak periods, this system could be combined with the use of cross-currents, by opening the window in the southeast-facing bedroom on the first floor. This would increase air velocity and thus create a higher level of body heat loss.

This passive cooling system would provide a higher level comfort in summer than blowing conditioned air, as well as significant energy savings. Construction of the house included preinstallation of an air conditioning system, consisting of supply and return ducts where indoor units or evaporators might be located, $230 \mathrm{v}$ wiring, evaporator condensation drainpipes and copper piping for R410A refrigerant distribution. Thus, if air conditioning were to become necessary during occupation of the building, devices could be installed on the roof without requiring further work indoors. After more than 8 years of occupation, it has not been necessary to install an air conditioning system, in other words, no additional air conditioning has been employed in summer. The only modification has been the installation of hot water radiators heated by a natural gas boiler in the winter.

\section{MONITORING THE HOUSE}

The house was monitored using sensors (wall surface temperature, indoor air temperature, outside air temperature, relative humidity, air velocity and solar radiation) located at strategic 
points on the external walls. The data obtained by the sensors were sent to a data logger, which transmitted the signal via a GPRS to a database. This information was accessible from a web platform. The GRD GSM/GPRS data logger can record data via analogue or digital channels. The data are sent to a server via the GSM/GPRS modem and can be viewed online in graph and table format. They can also be downloaded as a CSV file (Fig. 6). We collected data throughout an entire year in 2012.

\section{CALCULATION OF COMFORT}

Once data had been collected on indoor air temperatures, surface temperatures, relative humidity, etc., in the living room in the basement and the living room on the ground floor, for the worst case on July 1 at 15:00 h, we conducted a comparative calculation of the sensation of comfort in the basement according to Fanger's method described in section 5. Three cases were compared:

- OP 1. A house with the same geometry, but without a basement and built in the traditional style with $50 \mathrm{~cm}$ thick masonry walls and a sloping, tiled roof without thermal insulation.

- OP 2. Identical to the house constructed, but without a basement, where the floor slab on the ground floor was in contact with the ground, with thermal insulation.

- $\quad$ OP 3. The present house, with passive cooling from the basement.

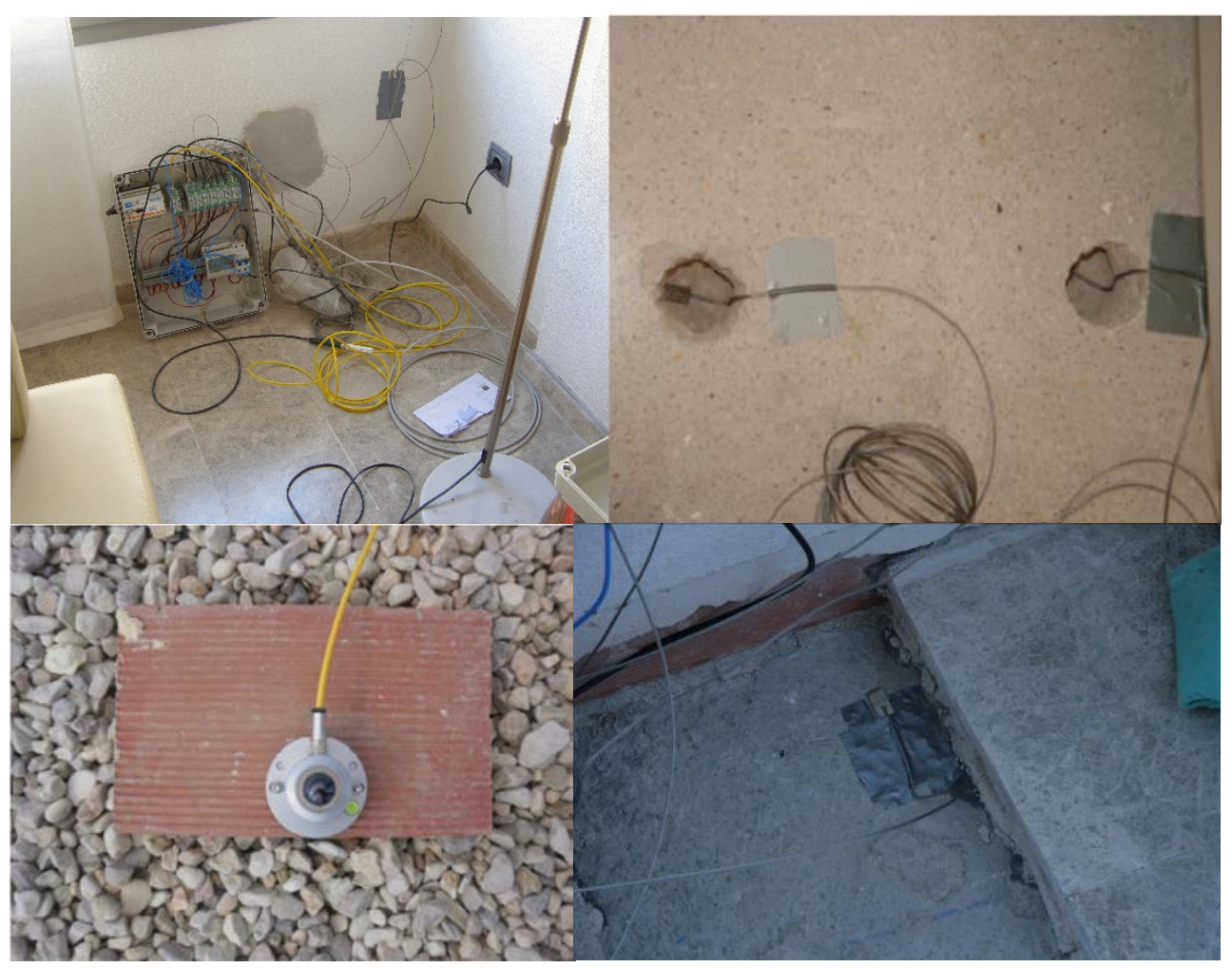

Figure 6: Data logger and sensors in the basement. Pyranometer on the roof. 
To perform these calculations for models 1 and 2, parameter values were obtained using the Design Builder tool, under the conditions described in section 9.

Table 1 presents the results for comparative comfort. As can be seen, total body heat loss per person $q_{c v i}+q_{r d i}$ was $85 \%$ higher in OP 3 than in OP2, mainly because the air temperature was $3.09^{\circ} \mathrm{C}$ lower and the $T_{r m}$ of the wall surfaces was $3.18^{\circ} \mathrm{C}$ lower. In the basement, total loss $q_{c v i}+q_{\text {rdi }}$ was $32 \%$ higher than that on the ground floor. Given that usual comfort values are around 90-100 $\mathrm{W}$ of loss per person, we can conclude that the house built in a traditional style was satisfactory in summer, as was the house analysed, built using a bioclimatic technique (Table 2). The basement provided superb comfort levels. However, levels of comfort in the modern house without a basement (OP2) were far from satisfactory, and it would be necessary to use an HVAC system in summer.

\section{CALCULATION OF ENERGY DEMAND FOR THE HOUSE}

To perform simulations of the building's performance in terms of energy demand and interior comfort parameters, the following data were entered into the Design Builder tool (Fig. 7). Winter was defined as encompassing the period from December 1 to April 30, and summer from May 1 to November 30. Setpoint temperatures for indoor air were $20^{\circ} \mathrm{C}$ in winter and $24^{\circ} \mathrm{C}$ in summer. Occupation, for standard calculation of air renewal, was 8 people. Based on the Spanish Technical Building Code, a value of $0.63 \mathrm{ren} / \mathrm{h}$ was established for air renewal. Air infiltration through the building envelope was moderate thanks to the quality of

Table 1: Body heat transfer in summer. Ground floor.

\begin{tabular}{cccccccccc}
\hline & $\boldsymbol{v}$ & $\boldsymbol{h}_{\boldsymbol{c}}$ & $\boldsymbol{T}_{\boldsymbol{p}}$ & $\boldsymbol{T}_{\boldsymbol{a}}$ & $\boldsymbol{h}_{\boldsymbol{r}}$ & $\boldsymbol{T}_{\boldsymbol{r m}}$ & $\boldsymbol{q}_{\boldsymbol{c v i}}$ & $\boldsymbol{q}_{\boldsymbol{r d i}}$ & TOTAL \\
\hline & $\mathrm{m} / \mathrm{s}$ & $\mathrm{W}^{\circ} \mathrm{C}$ & ${ }^{\circ} \mathrm{C}$ & ${ }^{\circ} \mathrm{C}$ & $\mathrm{W} / \mathrm{m} 2{ }^{\circ} \mathrm{C}$ & ${ }^{\circ} \mathrm{C}$ & $\mathrm{W}$ & $\mathrm{W}$ & $\mathrm{W}$ \\
\hline OP 1 & 0.068 & 7.401 & 30.00 & 26.11 & 4.70 & 18.45 & 28.79 & 54.28 & 83.08 \\
\hline OP 2 & 0.050 & 6.875 & 30.00 & 28.37 & 4.70 & 22.70 & 11.21 & 34.31 & 45.52 \\
\hline OP 3 & 0.092 & 7.958 & 30.00 & 25.28 & 4.70 & 19.98 & 37.56 & 47.09 & 84.65 \\
\hline
\end{tabular}

Table 2: Body heat transfer in summer. Basement.

\begin{tabular}{|c|c|c|c|c|c|c|c|c|c|}
\hline & $v$ & $\boldsymbol{h}_{c}$ & $T_{p}$ & $T_{a}$ & $\boldsymbol{h}_{r}$ & $T_{r m}$ & $\boldsymbol{q}_{c v i}$ & $q_{r d i}$ & TOTAL \\
\hline & $\mathrm{m} / \mathrm{s}$ & $\mathrm{W} /{ }^{\circ} \mathrm{C}$ & ${ }^{\circ} \mathrm{C}$ & ${ }^{\circ} \mathrm{C}$ & $\mathrm{W} / \mathrm{m} 2^{\circ} \mathrm{C}$ & ${ }^{\circ} \mathrm{C}$ & W & W & W \\
\hline OP 3 & 0.062 & 7.24 & 30.00 & 22.16 & 4.70 & 18.28 & 56.75 & 55.09 & 111.84 \\
\hline
\end{tabular}

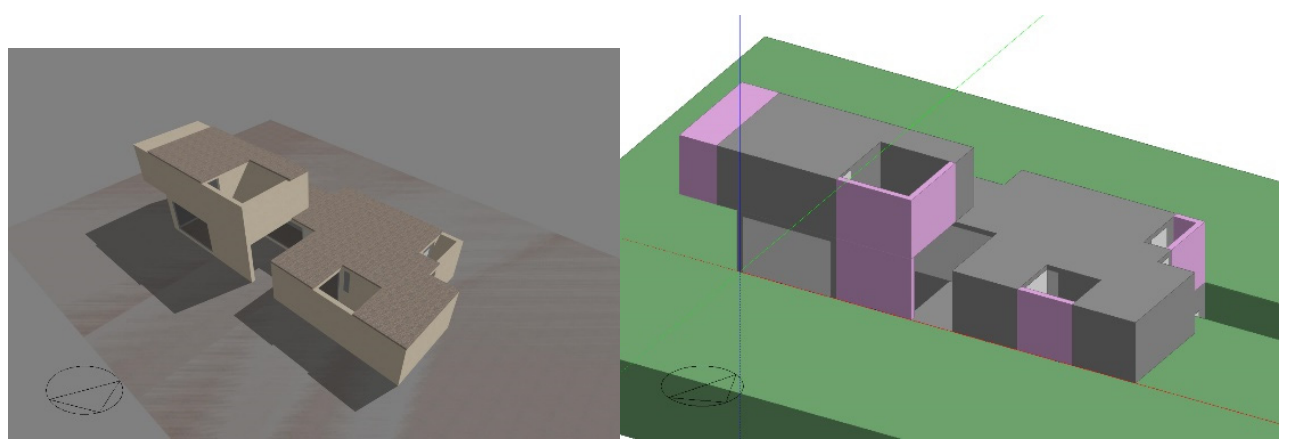

Figure 7: Modelling images in Design Builder. 
the doors and windows. The initial air renewal value considered was $0.7 \mathrm{ren} / \mathrm{h}$, which was subsequently adjusted in the calibration phase. The calculation did not include an air conditioning system in summer, since the house does not require it in practice, but did include a heating system in winter based on hot water radiators. An air infiltration value of $2.5 \mathrm{ren} / \mathrm{h}$ was included for OP1.

We then simulated the performance of the three housing options described above, in order to compare energy demands in summer and winter and quantify the energy savings obtained from the basement passive cooling system (Table 3). To fit the parameters obtained from simulation to real data, or calibrate the model, we used the values for indoor air and retaining wall temperatures in the basement obtained from monitoring OP3. We also entered the climate file for outside air temperature, relative humidity and solar radiation levels as measured by a pyranometer, obtained in Alicante in previous studies [13]. The wall surface temperature was corrected and the infiltration value was adjusted to $1.15 \mathrm{ren} / \mathrm{h}$ to calibrate the model by adjusting air and retaining wall temperatures to the values obtained from monitoring.

Figs $8-10$ show the temperature gradients produced in the simulation of the different spaces. The house with a basement presented a reduction in air temperature of around $3.2^{\circ} \mathrm{C}$.

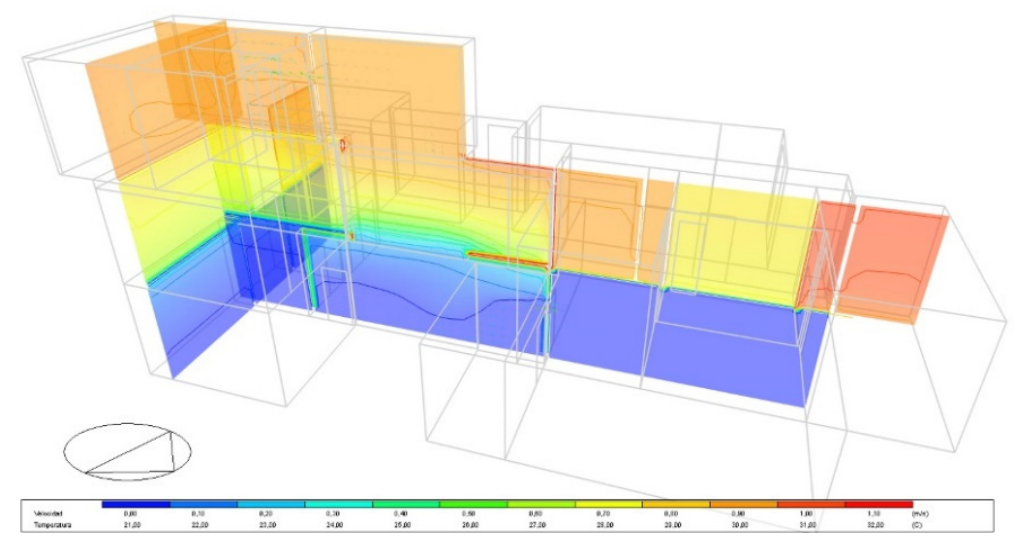

Figure 8: Indoor air temperatures. July 1 at 15:00 h. With basement.

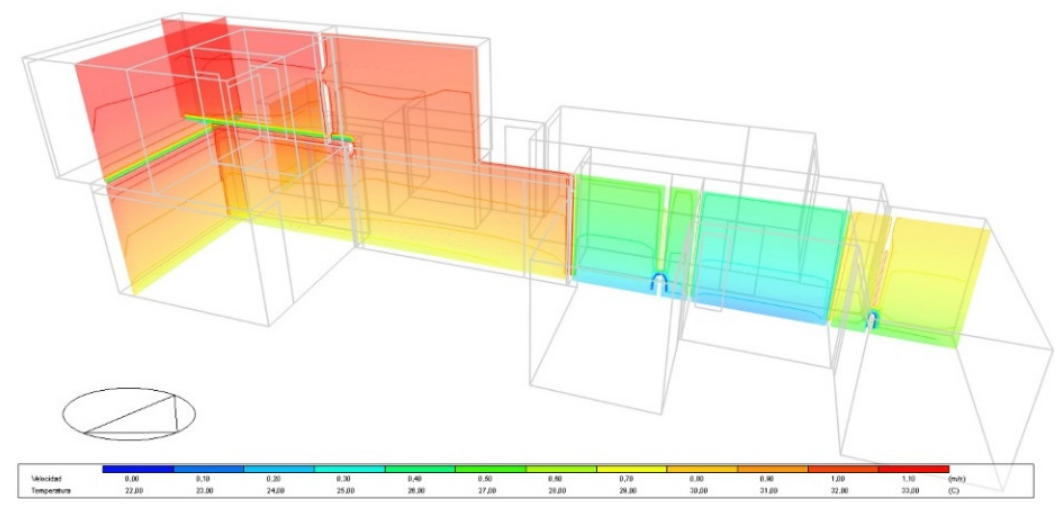

Figure 9: Indoor air temperatures. July 1 at 15:00 h. Without basement. 


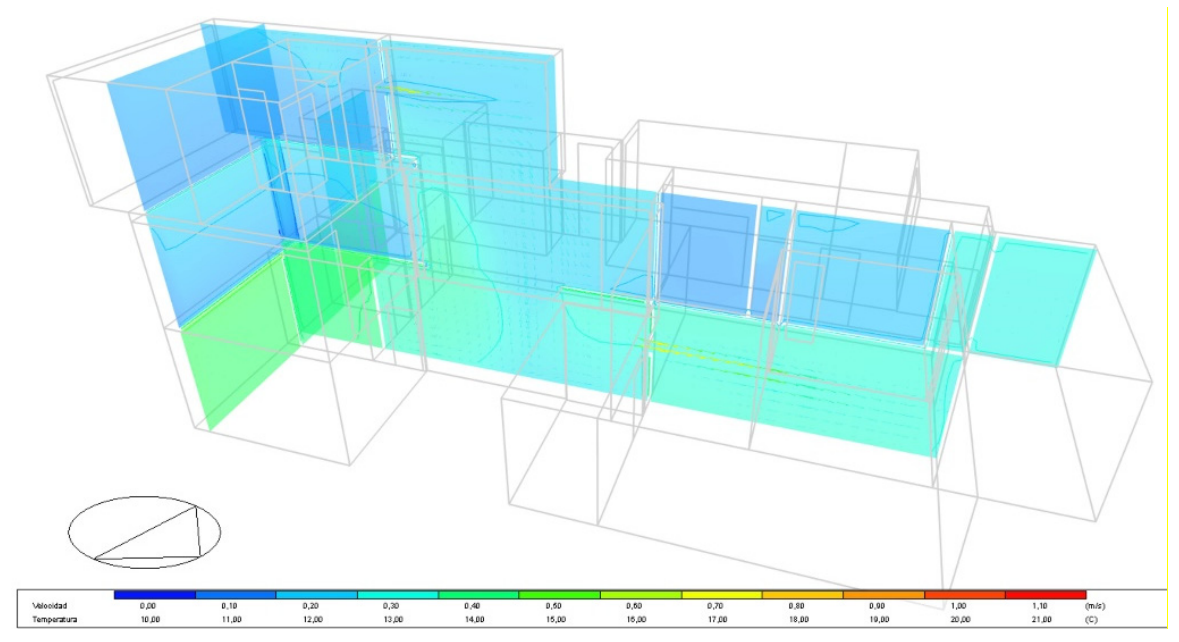

Figure 10: Indoor air temperatures. January 31 at 07:00 h. With basement.

Table 3: Calculation of energy demand and $\mathrm{CO}_{2}$ emissions for the 3 housing options (OP).

\begin{tabular}{lccc}
\hline & OP 1 & OP 2 & OP 3 \\
\hline Energy demand in summer $\mathrm{kWh} / \mathrm{m}^{2}$ & 33.80 & 37.3 & 30.15 \\
\hline Energy demand in winter $\mathrm{kWh} / \mathrm{m}^{2}$ & 42.57 & 25.63 & 20.20 \\
\hline Annual energy demand $\mathrm{kWh} / \mathrm{m}^{2} \mathrm{a}$ & 76.37 & 62.93 & 50.35 \\
\hline Annual $\mathrm{CO}_{2}$ emissions during occupation & $153.504 \mathrm{~kg}$ & $126.489 \mathrm{~kg}$ & $101.203 \mathrm{~kg}$ \\
\hline Percentage & $\mathbf{1 0 0 \%}$ & $\mathbf{8 2 . 4 0 \%}$ & $\mathbf{6 5 . 9 2 \%}$ \\
\hline
\end{tabular}

To quantify $\mathrm{CO}_{2}$ emissions from the electricity mix, we used the ELCD database, according to which the production of $1 \mathrm{kWh}$ electricity generates $0.41 \mathrm{~kg} \mathrm{CO}_{2}, 0.00122 \mathrm{~kg}$ $\mathrm{CH}_{4}$ and $0.0000465 \mathrm{~kg} \mathrm{~N}_{2} \mathrm{O}$ [14], [15]. To convert final end-user energy consumption to primary energy consumption and $\mathrm{CO}_{2}$ emissions, we used the Spanish Institute for Energy Diversification and Saving factors for 2010, namely $2.21 \mathrm{MWh}_{\mathrm{p}} / \mathrm{MWh}_{\mathrm{f}}$ and 0.27 $\mathrm{tCO}_{2}$ eq/MWh.

\section{CONCLUSIONS}

Use of the ground to moderate air temperature variations inside buildings in summer and winter significantly affects both comfort and energy demand. In single unit dwellings with a basement, especially those in climates with higher temperatures and relative humidity in summer, a design that permits convection currents to reach the upper floors yields a significant improvement in comfort and a significant reduction in energy demand. This bioclimatic technique may be more effective than the use of walls and roofs with high thermal inertia. The newly built house analysed here, located on the coast of the Spanish Levante, performed better than traditional houses with thick masonry walls and gable roofs. In these latter, the thermal inertia of the walls moderates heat in summer, but the energy demand is high in winter due to the high rate of air infiltration, at around $2.5 \mathrm{ren} / \mathrm{h}$. In contrast, the rate of air infiltration obtained for the newly built house by calibration was $1.15 \mathrm{ren} / \mathrm{h}$, reducing 
the annual energy demand by $18 \%$ compared with traditional housing. When combined with passive cooling from the basement, the energy demand is still further reduced to $20 \%$. Under these conditions, the indoor air and wall surface temperature on the ground floor was reduced by around $3^{\circ} \mathrm{C}$, improving the sensation of comfort by $85 \%$. Air conditioning has not been necessary in the house in summer. In winter, the conditions are less favourable, and it has been necessary to install heating based on hot water radiators.

\section{REFERENCES}

[1] CTE, Código Técnico de la Edificación. R/D 314/2006, de 17 de marzo. http://www.codigotecnico.org/images/stories/pdf/realDecreto/RD3142006.pdf

[2] HULC, Herramienta unificada Lider-Calener. Orden FOM/1635/2013, de 10 de septiembre (BOE de 12 de Septiembre), por la que se actualiza el Documento Básico DB HE, Ahorro de Energía, del CTE.

[3] Bedoya, C. \& Neila, J., Técnicas arquitectónicas y constructivas de Acondicionamiento ambiental, Ediciones Munilla-Lería: Madrid, 1997.

[4] García-Romero, A. \& Diarce, G., Phase change materials, PCMs, for thermal energy storage and their use in buildings. Arquitectura Ecoeficiente (Vol. I, Chap. 2), eds R. Hernández et al., Servicio Editorial de la UPV/ EHU: San Sebastián, pp. 97-115, 2012.

[5] Echarri Iribarren, V., Invariantes formales de la arquitectura tradicional de la Vega Baja del Segura, Diputación Provincial de Alicante: Alicante, 2000.

[6] NBE CT-79, Norma Básica de la Edificación NBE. Condiciones Térmicas de los edificios. R/D 2429/1979, 6 July.

[7] Fanger, O.P., Thermal Comfort. Analysis and Applications in Environmental Engineering, McGraw-Hill Book Company: New York, 1970.

[8] Ortega, M. \& Ortega A., Calefacción y refrescamiento por superficies radiantes, Paraninfo, Thomson Learning: Madrid, 2001.

[9] American Society of Heating, Refrigeration and Air Condiotioning Engineers, Handbook of Fundamentals, ASHRAE: Atlanta, 2010.

[10] Sala Lizarraga, J.M., Transmisión de calor en edificios. Arquitectura Ecoeficiente (Vol. I, Chap. 2), eds R. Hernández et al., Servicio Editorial de la UPV/ EHU: San Sebastián, 2012.

[11] Echarri Iribarren, V., Espinosa Fernández, A. \& Galiano Garrogós, A., Energy efficiency on flooded roofs: The University of Alicante Museum. WIT Transactions on Engineering Sciences, 106, pp. 163-176, 2016.

[12] UNE EN ISO 13786:2011. Thermal performance of building products and components. Dynamic thermal characteristics. Calculation methods.

[13] Echarri Iribarren, V., Galiano Garrigós A.L. \& González Avilés, A.B., Ceramics and healthy heating and cooling systems: Thermal ceramic panels in buildings. Conditions of comfort and energy demand versus convective systems. Informes de la Construcción, 68(544), pp. 19-32, 2016.

[14] Oregi, X., Hernández, P., Gazulla, C. \& Isasa, M., Integrating simplified and full life cycle approaches in decision making for building energy refurbishment: Benefits and barriers. Buildings, 5(2), pp. 354-380, 2015.

[15] ELCD Database, http://eplca.jrc.ec.europa.eu/ELCD3/datasetDownload.xhtml 